\title{
OS CAMINHOS PARA A TITULAÇÃO DE TERRITÓRIOS REMANESCENTES QUILOMBOLAS NO BRASIL
}

\author{
THE MEANS FOR THE TITLING OF REMAINING \\ QUILOMBOLA TERRITORIES IN BRAZIL
}

\author{
Silvana Araújo Maciel \\ Universidade Federal do Piauí, Pós-Graduação \\ (Mestrado PPGGEO/UFPI) em Geografia \\ silmaciel@outlook.com
}

Raimundo Wilson Pereira dos Santos Universidade Federal do Piauí (Docente), Pós-Graduação (Doutorado IGC/UFMG) em Geografia wilsonpereira@ufpi.edu.br

\section{Resumo}

A principal bandeira do negro sempre foi a resistência ao sistema que os excluiu por séculos. Assim, inúmeros direitos foram adquiridos, inclusive o direito ao território historicamente habitado. Diante disso, a pesquisa teve como objetivo geral analisar as etapas do processo de titulação de territórios quilombolas no Brasil. Utilizou-se, na metodologia, da pesquisa bibliográfica - principalmente em Treccani (2006), Fiabani (2017), Arruti (2016) e INCRA SR 24 (2019) - utilizando-se uma abordagem qualitativa, do tipo descritiva. Ademais, foi realizada pesquisa documental em material da Fundação Cultural Palmares - FCP e do Instituto Nacional de Colonização e Reforma Agrária INCRA (Superintendência Regional - SR 24). Na pesquisa de campo, entrevistou-se um representante do INCRA SR 24, para obter maiores esclarecimentos sobre o andamento do processo de regularização fundiária dos territórios quilombolas no Brasil. Constatouse que a conquista da titulação dos territórios quilombolas passa por questões burocráticas e acontece de forma muito lenta, mesmo após a inserção do artigo 68 do Ato das Disposições Constitucionais Transitórias - ADCT, na Constituição Federal, que garante as comunidades remanescentes quilombolas o direito aos territórios tradicionalmente ocupados. A titulação dos territórios quilombolas possibilita uma maior adoção de políticas públicas governamentais específicas de melhoria nas condições de vida dessas comunidades, apesar do processo nem sempre garantir a efetividade de tais políticas.

Palavras - chave: Quilombolas. Resistência. Território. Direitos. Titulação.

\begin{abstract}
The main banner of the black (African-Brazilian) people has always been resistance to the system that excluded them for centuries. Thus, countless rights were acquired, including the right to their historically inhabited territory. In view of this, the general objective of this research was to analyse the stages in the process of titling Quilombola territories in Brazil. The methodology used a bibliographical research - mainly Treccani (2006), Fiabani (2017), Arruti (2016) and INCRA SR 24 (2019) - using a qualitative and
\end{abstract}


descriptive approach. Furthermore, documentary research was conducted on material from the Palmares Cultural Foundation - FCP and the National Institute for Colonization and Agrarian Reform - INCRA (Regional Superintendence - SR 24). In the field research, in order to obtain further clarification on the progress of the land regularization process of Quilombola territories in Brazil, a representative from INCRA SR 24 was interviewed to do so. It was noted that the achievement of titling of Quilombola territories goes through bureaucratic issues and happens very slowly, even after the insertion of Act ADCT (Article 68 of the Transitory Constitutional Dispositions), in the Federal Constitution, which guarantees to the remaining Quilombola communities the right to traditionally occupied territories. The titling of Quilombola territories enables greater adoption of specific government public policies to improve the living conditions of these communities, although the process does not always guarantee the effectiveness of such policies.

Keywords: Quilombolas. Resistance. Territory. Rights. Titling.

\section{Introdução}

O conceito de território está em constante transformação e, historicamente, esteve ligado a expansão territorial e as relações de poder. O entendimento da territorialidade, a partir de uma visão histórico-cultural, está relacionado à apropriação política e simbólica do território. Saquet (2009) entende o território como o:

[...] produto de ações históricas que se concretizam em momentos distintos e sobrepostos [...] a territorialização é resultado e condição dos processos sociais e espaciais, significa movimento histórico e relacional. (SAQUET, 2009, p. 81).

Haesbaert (2011) conceitua o território como um espaço de dominação e/ou apropriação, que possui um sentido multiescalar e multidimensional, apreendido na multiplicidade de uma multiterritorialidade. Nessa visão, o território seria funcional e simbólico, tendo em vista a dominação do homem, que lhe dá funções e significados, tornando-o funcional.

Os territórios são compreendidos de maneiras distintas pelos diferentes sujeitos, que o caracterizam de acordo com os seus interesses e/ou intenções, dando ao conceito maior amplitude ou restringindo-o. Assim, a totalidade de um território é determinada pelas dimensões de sua escala geográfica e pelas relações sociais presentes nele.

Destarte, compreende-se, a partir da análise do conceito de território no contexto geográfico, que, inicialmente, a identidade em comunidades quilombolas possui 
características políticas, sociais e culturais. Entretanto, à medida que o processo produtivo e a organização do espaço vão sendo implementados, tal identidade se redimensiona em territorialidade, a qual é composta por relações simétricas que colaboram na construção de identidades e significações próprias desses territórios.

Nesse contexto, ressalta-se que os quilombolas contemporâneos enfrentam condições adversas na garantia de sua vivência, bem como no enfrentamento e fortalecimento da comunidade na luta constante pelo território, contra o preconceito, a discriminação étnica, o racismo e o fortalecimento de uma identidade baseada em raízes históricas. Inácio e Santos (2018), ao abordarem as territorialidades dos povos tradicionais destacam que:

\begin{abstract}
A sua vivência no lugar é multidimensional, pois, está além da sobrevivência, também envolvem os aspectos sociais, culturais, os valores e os modos de vida que vão se constituindo ao longo do tempo e que ultrapassam gerações, permanecendo mesmo sob as pesadas imposições da lógica capitalista que desconsidera as demais questões apresentadas. (INÁCIO; SANTOS, 2018, p. 47).
\end{abstract}

Ademais, o avanço do capitalismo sobre áreas antes consideradas improdutivas e sem nenhum atrativo comercial, tem ameaçado a existência das comunidades quilombolas, que temem perder seus territórios, pois na grande maioria dos casos, a posse é a única garantia de permanência, sem a escrituração para comprovar a sua legalidade.

Assim, as comunidades remanescentes de quilombos resistem às pressões de latifundiários sobre seus territórios, com a territorialização constituindo-se na luta para continuar a existir, a partir da manutenção e, em alguns casos, da reinvenção, de uma identidade política e cultural. Para essas comunidades, o diálogo com o Estado é fundamental na reivindicação do título do território e na destinação de políticas públicas para o desenvolvimento socioespacial local.

Essas comunidades também são conhecidas como "mocambos", "comunidades negras rurais", "quilombos contemporâneos", "comunidades quilombolas" ou "terras de preto" (ANJOS, 2003). Estas territorializam o espaço e buscam conviver de forma pacífica. Entretanto, seus processos de luta pelo território demandam uma organização em diferentes escalas.

As comunidades remanescentes de quilombos estão localizadas em todas as regiões do Brasil. Os dados do Mapa 1 revelam uma elevada concentração destas na 
região Nordeste, confirmando os estudos sobre a presença marcante da escravidão nessa região do País. As informações do Censo Agropecuário (2017) revelaram ainda que, em todo o Brasil, existem 1.358 (um mil trezentos e cinquenta e oito) estabelecimentos agropecuários com terras ${ }^{1}$ quilombolas em fase de regularização fundiária e titulação.

Mapa 1: Número de estabelecimentos agropecuários com terras de titulação de comunidades quilombolas - 2017

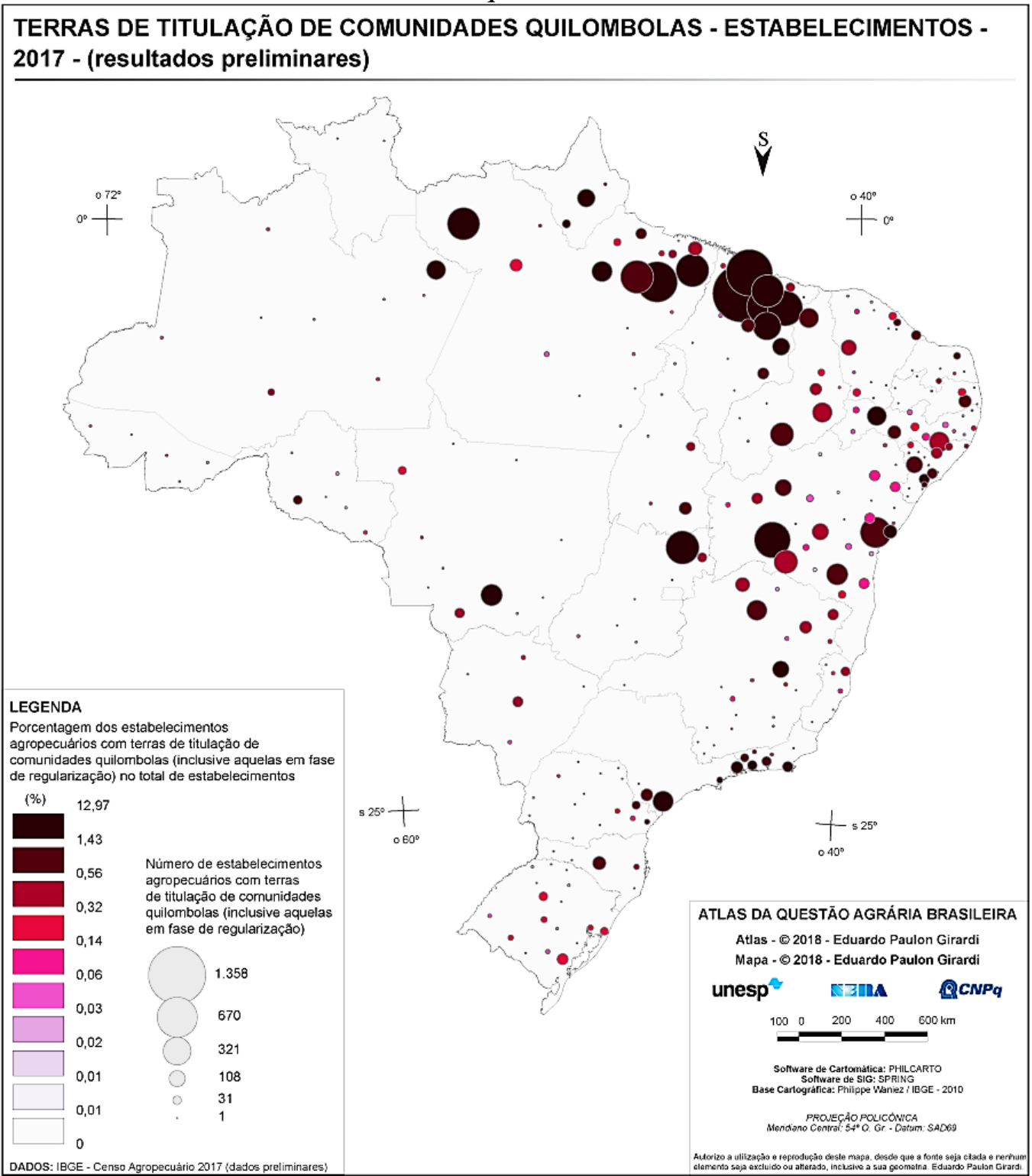

Fonte: Organizado por Girardi (2018).

Disponível em: www.atlasbrasilagrario.com.br.

\footnotetext{
${ }^{1} \mathrm{O}$ substantivo terra ao longo do texto será usado como sinônimo território.
} 
Os remanescentes quilombolas têm na resistência sua principal bandeira de luta. Dessa maneira, inúmeros direitos foram adquiridos, inclusive o direito ao território historicamente habitado. Entretanto, a titulação de seus territórios ainda é tida como um sonho distante para a grande maioria das comunidades remanescentes quilombolas do Brasil. A partir dessa problemática, questionou-se: quais as etapas do processo de titulação dos territórios quilombolas no Brasil? Quais as causas da burocratização nos trâmites legais do processo de titulação dos territórios quilombolas o Brasil?

Partindo dessa problemática, este trabalho teve, como objetivo geral, analisar as etapas do processo de titulação de territórios quilombolas no Brasil. E como objetivos específicos: entender as etapas legais do processo de titulação de territórios quilombolas no Brasil; identificar as causas do atraso na execução das etapas do processo de titulação de territórios quilombolas no Brasil; e apontar conflitos no processo jurídico-territorial para a titulação dos territórios quilombolas no Brasil.

Este artigo está estruturado a partir das abordagens de temáticas sobre a origem das lutas pelos territórios quilombolas, a resistência quilombola no Brasil, o artigo 68 do ADCT e os caminhos para a titulação dos territórios quilombolas.

\section{Procedimentos metodológicos}

No percurso metodológico, inicialmente utilizou-se a pesquisa bibliográfica em livros (impressos e/ou digitais), artigos de periódicos, dissertações, teses, leis, documentos, etc., os quais abordavam temáticas pertinentes ao estudo. Esse tipo de pesquisa procede da escolha de um tema ou assunto que será desenvolvido, assim como da elaboração de um plano de trabalho provisório, estando sujeita a modificações no transcorrer do seu percurso. Sobre a pesquisa bibliográfica, Gil (2009) destaca que:

As fontes bibliográficas mais conhecidas são os livros de leitura corrente. No entanto, existem muitas outras fontes de interesse para a realização de pesquisas, tais como: obras de referência, teses e dissertações, periódicos científicos, anais de encontros científicos e periódicos de indexação e resumo. (GIL, 2009, p. 61). 
A construção do referencial teórico possibilitou o aprofundamento da abordagem qualitativa, e um melhor entendimento da luta pelos territórios quilombolas no Brasil, destacando a resistência do negro ${ }^{2}$ nesse processo de busca por direitos e afirmação.

Os documentos utilizados e analisados durante a pesquisa foram adquiridos no INCRA SR 24, nos sites da FCP, do INCRA e da Coordenação Nacional de Articulação das Comunidades Negras Rurais Quilombolas - CONAQ. A partir dessas fontes, coletouse informações e dados sobre as comunidades quilombolas do Brasil, que possibilitaram análises sobre a problemática em questão. Sobre a pesquisa documental Lakatos e Marconi (2010) afirmam que:

a característica da pesquisa documental é que a fonte de coleta de dados está restrita a documentos, escritos ou não, constituindo o que se denomina de fontes primárias. Estas podem ser feitas no momento em que o fato ou fenômeno ocorre, ou depois. (LAKATOS; MARCONI, 2010, p. 157).

Para a elaboração dos mapas foi utilizado o software QGIS versão 2.18.10, tendo como referencial geodésico o sistema de referência geocêntrico para as Américas SIRGAS 2000. Utilizou-se também a base de dados cartográficos do IBGE (2015; 2017) e do INCRA SR 24 (2019) para a organização e geoprocessamento dos dados.

$\mathrm{Na}$ busca por informações mais detalhadas sobre o processo de titulação de territórios quilombolas no Brasil, elaborou-se um roteiro de entrevista, o qual foi direcionado a um representante do INCRA SR 24.

Enquanto técnica de coleta de dados, a entrevista é bastante adequada para a obtenção de informações acerca do que as pessoas sabem, creem, esperam, sentem ou desejam, pretendem fazer, fazem ou fizeram, bem como acerca das suas explicações ou razões a respeito das coisas precedentes. (SELLTIZ et al., 1967 citado por GIL, 2009, p. 109).

Os dados coletados a partir da aplicação de entrevista com o representante do INCRA SR 24 foram de grande relevância, pois permitiram a descrição e análise mais

\footnotetext{
${ }^{2}$ De acordo com a convenção do IBGE, portanto, negro é quem se autodeclara preto ou pardo. Embora a ancestralidade determine a condição biológica com a qual nascemos, há toda uma produção social, cultural e política da identidade racial/étnica no Brasil (OLIVEIRA, 2004, p. 57).
} 
detalhada do processo de titulação dos territórios quilombolas no Brasil, bem como apontar as causas inerentes a morosidade dessas titulações.

\section{A origem dos territórios quilombolas no Brasil}

A conquista do território brasileiro pelo colonizador português no século XVI impôs um sistema de uso da terra à população indígena, então habitante, e aos negros, usados como mão de obra escrava. O negro escravizado teve uma participação expressiva na economia brasileira desde a sua chegada ao país, sendo utilizado como mão de obra na cultura da cana-de-açúcar. Os escravos trazidos para o Brasil, além de ajudarem nos trabalhos dos engenhos, minas, plantações, fábricas, cozinhas e salões, marcaram aspectos da cultura material e espiritual do país.

A escravidão esteve presente em todas as regiões do país, com os escravos sendo distribuídos de formas variadas e de acordo com os interesses da economia colonial. Entretanto, havia uma maior concentração na Bahia, Rio de Janeiro, São Paulo, Pernambuco, Alagoas, Paraíba, Maranhão e Minas Gerais. Desses centros polarizadores, os escravos eram irradiados para as demais áreas do país. "Em 1819, conforme estimativa oficial, nenhuma região tinha menos de $27 \%$ de escravos em sua população" (MOURA, 1993, p. 8).

Uma das marcas da escravidão foi a resistência do negro à sua condição de escravo. Sobre as fugas de escravos no Brasil, Reis e Gomes (2012, p. 10) relatam que era "a fuga que levava a formação de grupos de escravos fugidos, aos quais frequentemente se associavam outras personagens sociais".

As formas de organização dos escravos eram variadas (guerrilhas, insurreições urbanas, banditismo, quilombos, dentre outras), porém os quilombos não foram apenas sinônimo de rebeldia contra a escravidão, representavam um protesto contínuo e a negação ao sistema escravista. "A palavra quilombo é originária do idioma africano quimbunco, que significa: sociedade formada por jovens guerreiros que pertenciam a grupos étnicos desenraizados de suas comunidades" (CONAQ, 2019, n.p.).

A fuga para o quilombo representava a reelaboração de comunidades livres dos castigos e das opressões. Era uma forma de combate contra a dominação militar, política e ideológica. A fuga do negro escravizado para os quilombos, fez surgir "o território da 
liberdade negra da África no Brasil" (OLIVEIRA, 1994, p. 16). Palmares representou o maior exemplo de conflito pela defesa de um território composto pelos escravos fugitivos que buscavam liberdade na sua resistência.

A crise do escravismo, na segunda metade do século XIX, e a intensificação do sistema capitalista, aliados às pressões da Inglaterra, acabaram por obrigar o Brasil a extinguir o regime escravista. O movimento abolicionista trouxe consigo uma proposta política favorável a liberdade dos escravos a nível nacional. De acordo com Albuquerque e Fraga Filho (2006, p. 194) "diante desse quadro de tensões crescentes, a princesa regente promulgou a Lei de 13 de maio de 1888 que extinguiu em definitivo a escravidão no Brasil”.

A Lei Áurea representou o maior avanço da luta e da resistência negra, revolucionando o sistema escravista até então adotado. Entretanto, essa lei não contemplou o desenvolvimento da agricultura, a criação de colônias agrícolas para abrigar os libertos ou a desapropriação de terras, medidas propostas pelos abolicionistas que acreditavam que o fim da escravidão deveria levar os libertos a propriedade da terra e a proteção da pequena produção em detrimento do latifúndio.

\section{Da abolição ao artigo 68 do Ato das Disposições Constitucionais Transitórias - ADCT}

Nas décadas de 1930 e 1940, a abolição da escravidão ainda era vista como um processo inacabado pela Frente Negra Brasileira (FNB). O movimento negro nasceu em 1931 com a fundação da FNB, como resposta ao mito da democracia racial, que ganhou força na sociedade brasileira, principalmente após a publicação do livro "Casa Grande \& Senzala", em 1933, por Gilberto Freyre. A FNB defendia que o Estado brasileiro possuía uma dívida que deveria ser redimida, por isso defendiam a ideia de "reparação histórica", justificada na gratuidade do trabalho do escravizado e nas situações de exclusão dos negros, que demandam a elaboração de políticas reparadoras e antirracistas (PEREIRA, 2010).

Nessas circunstâncias, surge o Movimento Negro Unificado (MNU), em 07 de julho de 1978. Essa organização luta contra a discriminação racial do povo negro no 
Brasil. Na época de sua criação, contestava a ideia adotada pelo Regime Militar de que o Brasil vivia uma democracia racial (ALBUQUERQUE; FRAGA FILHO, 2006).

$\mathrm{O}$ MNU foi influenciado pelas organizações negras norte-americanas, sobretudo o movimento Black Power. Sua base é urbana, mas atua em outras frentes, como a mobilização das Comunidades Remanescentes de Quilombos. Nesse sentido, o Artigo 68 é um instrumento fundamental para elevar as pressões do MNU sobre o Governo, reivindicando o seu cumprimento e aplicabilidade.

Durante o processo de aprovação do Artigo 68 do ADCT da Constituição Federal, o Brasil vivenciava intensos debates sobre as mudanças nos direitos civis e coletivos, duramente atacados no período da Ditadura Militar. Nesse contexto, a reforma agrária era apontada como uma das mais importantes reivindicações populares, por ser capaz de acabar com os principais problemas sociais e econômicos do campo brasileiro.

É significativo lembrar que a primeira proposta de inserção de artigo sobre a regularização e titulação dos territórios das populações remanescentes de antigos quilombos partiu da deputada Benedita da Silva, em 06 de maio de 1987 (FIABANI, 2017). Durante a Assembleia Constituinte para aprovação do artigo, o movimento negro se concentrou nas manifestações ligadas às questões raciais, educacionais e à liberdade religiosa, deixando de lado a luta das comunidades negras pela propriedade dos territórios ocupados.

O MNU teria elaborado uma proposta exigindo o direito aos territórios das comunidades negras, mas não conseguiu a quantidade de assinaturas necessárias, fato que levou a proposta a ser subscrita pelo Deputado Carlos Alberto Cáo, do Partido Democrático Trabalhista (PDT), resultando no Artigo 68 do ADCT (TRECCANNI, 2006).

A luta histórica dos negros pelas terras oriundas dos antigos quilombos só é reconhecida com as mudanças político-institucionais e administrativas assinaladas pela Constituição de 1988, que passou a regulamentar: "aos remanescentes das comunidades dos quilombos que estejam ocupando suas terras é reconhecida a propriedade definitiva, devendo o Estado emitir-lhes os títulos respectivos" (BRASIL, 1988, Art. 68 - ADCT).

A aprovação do referido artigo fez emergir para a sociedade o fenômeno quilombola, levando a muitos questionamentos sobre a existência de quilombos no pósabolição, ao passo que as comunidades negras ganharam notoriedade com a 
ressignificação do quilombo escravista. A partir da expressão "comunidades remanescentes de quilombos", Fiabani (2017) relata que

[...] houve resistência antes e depois da Abolição, ou seja, se antes os trabalhadores escravizados resistiam às ações dos destruidores de quilombos, após à Abolição as comunidades negras resistiram para não serem expulsas das suas terras. (FIABANI, 2017, p. 23).

A ressignificação do quilombo possibilitou a inclusão de mais comunidades negras nas questões relacionadas à aquisição da terra, não precisando que estas tenham surgido de um quilombo da época do cativeiro. Fiabani (2017) descreve a origem das comunidades negras nas seguintes matrizes:

Comunidades originadas de antigos quilombos, comunidades formadas em terras devolutas, comunidades que se constituíram em terras da Igreja ou de ordens religiosas, comunidades formadas a partir de terras compradas pelos cativos ou ex-cativos, comunidades constituídas em terras recebidas por herança, comunidades formadas em terras de fazendas abandonadas, comunidades que nasceram de doações de terras pelo Estado em troca de serviços guerreiros, comunidades nascidas em terras indígenas e também constituídas em terras destinadas para assentamentos organizados pelo Incra. (FIABANI, 2017, p. 26).

A grande maioria das comunidades remanescentes não se formou a partir dos quilombos do período da escravidão, visto que, ao longo dos 100 anos após a libertação, os negros migraram para áreas diferentes e formaram novas comunidades, urbanas e rurais. Dessa forma, deve-se considerar a infinidade de motivos que levaram às migrações, como a procura por emprego, esgotamento do solo, conflitos por terras, dentre outros.

Arruti (2016) alerta para inadequação institucional dos chamados "quilombos urbanos". Pensados como uma categoria híbrida, representam uma controvérsia para o movimento quilombola, diante do risco de expansão das reivindicações e o consequente enfraquecimento jurídico da questão territorial quilombola. $\mathrm{O}$ "quilombo urbano" possui diferentes eixos de variações, suas dinâmicas são induzidas e resultantes de processos de urbanização, sendo vulneráveis a diversos vetores desse processo e por eles impactados.

As comunidades quilombolas do Brasil possuem uma identidade étnico-racial diferenciada estruturalmente, por possuírem aspectos histórico-culturais associados à incorporação de elementos de todas as regiões do Brasil. Entretanto, Miné e Rodrigues 
(2012) afirmam que esses grupos se identificam na luta por melhores condições de vida, pois são pertencentes a uma mesma condição sócio-histórica nacional de marginalidade e têm como principal reivindicação o fim da situação de exclusão e o diálogo mais horizontal com o Estado.

Entretanto, é importante enfatizar que essas comunidades se constituem em territórios tradicionais, onde existe a reprodução da cultura, religião e da economia, que as caracterizam por preservar seus valores e tradições, mantidos e transmitidos para as gerações presentes em um processo de autovalorização e reconhecimento histórico nacional. Nessa concepção Treccani (2006) reconhece que:

[...] as comunidades remanescentes de quilombos não podem ser definidas em termos biológicos e raciais, mas com criações sociais que se assentam na posse e usufruto em comum de um dado território e na preservação e reelaboração de um patrimônio cultural e de identidade própria. (TRECCANI, 2006, p. 107).

Dessa forma, é notório que a construção da identidade do grupo não diga respeito apenas ao seu passado, mas à percepção de sua história no presente. Assim, é interessante observar que a aplicabilidade do Artigo 68 do ADCT passa necessariamente pela observação de outros artigos que a Constituição do Brasil, como quando traz como objetivo:

II - Erradicar a pobreza e a marginalização e reduzir as desigualdades sociais e regionais; IV - promover o bem de todos, sem preconceitos de origem, raça, sexo, cor, idade e quaisquer outras formas de discriminação [...] o Estado garantirá a todos o pleno exercício dos direitos culturais e acesso às fontes da cultura nacional, e apoiará e incentivará a valorização e a difusão das manifestações culturais [...] constituem patrimônio cultural brasileiro os bens de natureza material e imaterial, tomados individualmente ou em conjunto, portadores de referência à identidade, à ação, à memória dos diferentes grupos formadores da sociedade brasileira, [...]. (BRASIL, 1988, Art. $3^{\circ} ; 215^{\circ}$ )

Para Bernd (1994, p. 10), "a discriminação racial corresponde ao ato de apartar, separar, segregar pessoas de origens raciais diferentes". A partir do entendimento que existem raças inferiores e raças superiores, levando à delimitação de espaços diferentes para cada grupo étnico, o isolamento muitas vezes é imposto pela discriminação racial. 
De acordo com o entendimento de Treccani (2006, p. 109), "o direito dos quilombolas à terra está diretamente associado ao direito à preservação de sua cultura e organização social específica". Nesse sentido, a apropriação coletiva da terra passa pelo direito agrário e o direito étnico-cultural.

Para Treccani (2006), o Artigo 68 veicula as comunidades de quilombo ao seu território por meio do reconhecimento do domínio que garante a afirmação e continuidade das tradições desses grupos na sociedade. Nessa perspectiva, a imperatividade que acompanha o Artigo 68 deve-se ao fato da impossibilidade de descumprimento desse dever constitucional do direito dos remanescentes das comunidades quilombolas à terra.

Nessa perspectiva, Fiabani (2017, p. 18) reforça que, "pela primeira vez na história do Brasil, criou-se uma lei específica que beneficia o campesinato negro, ou seja, este artigo é a primeira norma que reconhece o direito à propriedade da terra às comunidades negras, até então invisíveis aos olhos do Estado". O Guia de Políticas Públicas da SEPPIR cita diversos instrumentos legais conquistados pelas Comunidades Quilombolas (Quadro 1).

Quadro 1: Instrumentos legais e normativos para comunidades quilombolas no Brasil.

\section{BASE LEGAL}

Constituição Federal de 1988 - Artigos 215 e 216 da Constituição Federal - Direito à preservação de sua própria cultura;

Artigo 68 do ADCT - Direito à propriedade das terras de comunidades remanescentes de quilombos.

Convenção 169 da Organização Internacional do Trabalho - OIT - (Dec. 5051/2004) Direito à autodeterminação de Povos e Comunidades Tradicionais.

Lei $\mathbf{n}^{\circ}$ 12.288, de 20 de julho de 2010 - Estatuto da Igualdade Racial.

Decreto no 4.887, de 20 novembro de 2003 - Trata da regularização fundiária de terras de quilombos e define as responsabilidades dos órgãos governamentais.

Decreto $\mathbf{n}^{\mathbf{0}}$ 6040, de 7 de fevereiro de 2007 - Institui a Política Nacional de Desenvolvimento Sustentável dos Povos e Comunidades Tradicionais.

Decreto $\mathbf{n}^{\mathbf{0}}$ 6261, de 20 de novembro de 2007 - Dispõe sobre a gestão integrada para o desenvolvimento da Agenda Social Quilombola no âmbito do Programa Brasil Quilombola.

Portaria Fundação Cultural Palmares no 98 de 26 de novembro de 2007- Institui o Cadastro Geral de Remanescentes das Comunidades dos Quilombos da Fundação Cultural Palmares, também autodenominadas Terras de Preto, Comunidades Negras, Mocambos, Quilombos, dentre outras denominações congêneres.

Instrução Normativa INCRA n ${ }^{\mathbf{5}}$ 57, de 20 de outubro de 2009 - Regulamenta o procedimento para identificação, reconhecimento, delimitação, demarcação, desintrusão, titulação e registro das terras ocupadas por remanescentes das comunidades dos quilombos.

Fonte: Programa Brasil Quilombola (2013, p 15). 
É notório lembrar que os remanescentes quilombolas no Brasil conquistaram diversos instrumentos legais que colaboram não somente na luta pelo território, mas na luta por direitos sociais, culturais e inserção econômica e produtiva.

O Movimento Negro e o apoio do Ministério Público Federal foram fundamentais na implementação o Artigo 68. Este movimento esteve à frente da primeira solicitação de titulação feita pela comunidade quilombola Rumo-Frechal (município de Mirinzal, estado do Maranhão), em 08 de novembro de 1991 (TRECCANI, 2006).

Apesar da solicitação da comunidade Rumo-Frechal não ter obtido êxito no reconhecimento do domínio, mas tão somente a concessão de direito real de uso, essa iniciativa serviu para despertar as demais comunidades do Brasil para a resolução dessa problemática.

O Artigo 68 do ADCT não esclarece qual órgão do governo é responsável pela execução das titulações e estabelecimento de normas do processo. Treccani (2006, p. 124) cita que "tanto a União quanto o Estado ou o município podem emitir o título". Assim, diante de discordâncias e conflitos sobre a questão, o INCRA e a FCP receberam e acompanharam processos de solicitação de titulações seguindo normas internas próprias.

Segundo Arruti (1997) o "artigo 68" não recebeu nenhuma proposta de regulamentação até 1995. Esse instrumento ganhou importância e passou a ser alvo de debates e reflexões de âmbito nacional quando foi associado as festividades pela memória de Zumbi de Palmares.

Treccani (2006) expõe que o INCRA foi o primeiro órgão a titular uma terra de quilombo. Trata-se da Comunidade de Boa Vista (Oriximiná-Pará), pela qual o INCRA criou, em novembro de 1995, uma equipe com a tarefa de elaborar e acompanhar a implementação da política quilombola.

Arruti (2009) destaca que as políticas voltadas para as comunidades quilombolas entre 1997 e 1999 se resumiram a realização de eventos e seminários temáticos, levantamentos de comunidades quilombolas no país e processos de reconhecimento e tombamento, executados pela Fundação Cultural Palmares, órgão vinculado ao Ministério de Cultura.

Dessa maneira, o referido ministério monopolizou as políticas para comunidades quilombolas até a publicação do Decreto n ${ }^{\circ} 4.887$, de 20 novembro de 2003, o qual definiu o Programa Brasil Quilombola, passando para a Secretaria Especial de Políticas de 
Promoção da Igualdade Racial - SEPPIR, a articulação das ações para os quilombolas, distribuindo-as em diferentes ministérios (ARRUTI, 2009).

Diante das solicitações de titulações, o INCRA teve que construir normas procedimentais para regularizar os territórios de antigos quilombos. Entretanto, somente com o Decreto $\mathrm{n}^{\circ} 4.887 / 2003$ as responsabilidades dos órgãos governamentais foram definidas no que tange à regularização fundiária de territórios remanescentes de quilombos:

Compete ao Ministério do Desenvolvimento Agrário, por meio do Instituto Nacional de Colonização e Reforma Agrária - INCRA, a identificação, reconhecimento, delimitação, demarcação e titulação das terras ocupadas pelos remanescentes das comunidades dos quilombos, sem prejuízo da competência concorrente dos Estados, do Distrito Federal e dos Municípios. O INCRA deverá regulamentar os procedimentos administrativos para identificação, reconhecimento, delimitação, demarcação e titulação das terras ocupadas pelos remanescentes das comunidades dos quilombos, dentro de sessenta dias da publicação deste Decreto. (BRASIL, 2003, Art. $3^{\circ} \S 1^{\circ}$ ).

Desse modo, ressaltamos que a redução das desigualdades sociais, assim como a valorização das manifestações culturais, sem preconceitos de qualquer origem, também são direitos essenciais para os remanescentes quilombolas. Partimos da ideia de que apenas o direito ao território não oferece segurança jurídica para transformar a realidade atual dessas comunidades. Percebe-se a necessidade da concretização do Decreto $\mathrm{n}^{\mathbf{o}}$ 4.887/2003, por intermédio da Instrução Normativa $n^{\circ}$ 57/2009 do INCRA, para assim promover uma maior afirmação e participação do negro na sociedade, sem preconceito e discriminação social e/ou racial.

Assim, o artigo 68 do ADCT foi uma conquista importante, pois possibilitou o reconhecimento legal dos territórios ocupados pelos remanescentes de comunidades quilombolas. Entretanto, o desafio da concretização, ou seja, da materialidade desse reconhecimento, por intermédio da demarcação e titulação dos territórios, passou a ser o maior problema que essas comunidades enfrentam na atualidade. Este dispositivo assegurou o direito de reivindicar os territórios por elas ocupadas. Nesse sentido, o reconhecimento as insere no espaço rural como movimento social que possui sua própria história na luta pelo território. 


\section{Territórios tradicionais e a resistência quilombola no Brasil}

A maioria dos conflitos por terra ao longo do processo de formação do território brasileiro não recebeu notoriedade nos escritos históricos, sendo esquecidos e considerados sem grande significância. Entretanto, com o crescente número de sujeitos sociais engajados na luta pela terra, esses conflitos ganharam maior visibilidade, acompanhada, porém, pelo aumento considerável no número de assassinatos no campo, assim como pela intensificação da concentração fundiária.

Almeida (2008) afirma que as dificuldades na efetivação dos dispositivos legais que garantem o direito as terras tradicionalmente ocupadas indicam que existe tensões no processo de reconhecimento jurídico-formal, tendo em vista o rompimento da invisibilidade social, impulsionando a transformação na estrutura agrária atuante.

$\mathrm{Na}$ luta pela terra, novos grupos sociais se juntam aos grupos pioneiros e, muitas vezes, inevitavelmente, se envolvem em conflitos pela posse da terra. Podemos citar os sem-terra, seringueiros, quilombolas, indígenas e quebradeiras de coco. Esses grupos sociais despertam na sociedade a necessidade de repensar o significado da reforma agrária. O Gráfico 1 mostra que de 2015 a 2018, no Brasil, houve uma forte atuação das comunidades tradicionais, dentre elas as remanescentes de quilombos, em conflitos pela posse da terra.

Gráfico 1: Distribuição dos conflitos no Nordeste, por categoria de trabalhadores rurais ш2015 $\approx 2016 \backsim 2017 \backsim 2018$

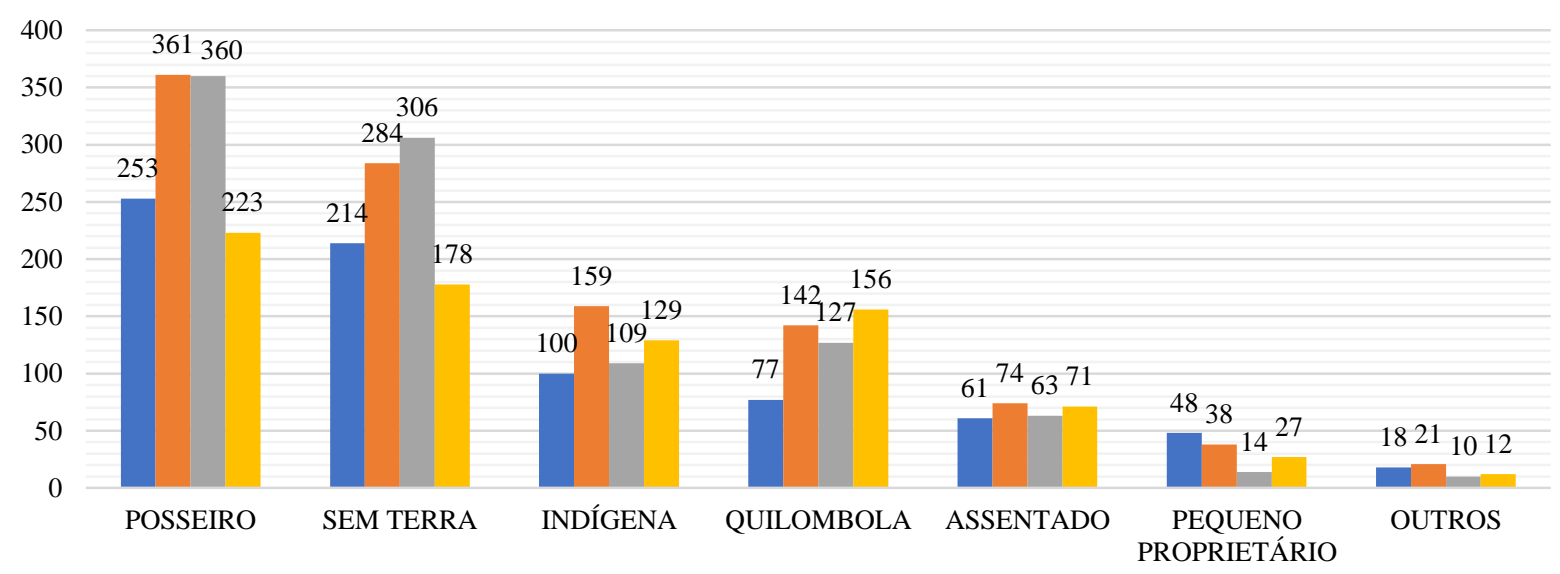

Fonte: Comissão Pastoral da Terra - CPT (2018).

Adaptado por Maciel (2020). 
Em todo o Brasil, as comunidades tradicionais "geralmente estão em posse real de uso das condições de reprodução da vida e, nesse sentido, a elevada proporção delas implicadas em conflitos indica que há um processo de despossessão pela expansão do capital/invasão de seus territórios [...]” (CANUTO; LUZ; ANDRADE, 2018, p. 116)

De acordo com Canuto, Luz e Andrade (2018, p. 44), no Nordeste, “[...] os quilombos entraram em conflito pela demarcação de seus territórios nos estados de Amapá, Maranhão, Bahia, Espírito Santo, Goiás, Minas Gerais, Pernambuco, Pará, Piauí e Rondônia”, durante o ano de 2015.

A organização quilombola no Brasil surgiu a partir do Movimento Nacional das Comunidades Negras Rurais Quilombolas, com configuração e articulação própria, a partir da década de 1990. “Em 1995, no I Encontro Nacional das Comunidades Negras Rurais Quilombolas, realizado durante a Marcha Zumbi dos Palmares é criada a Comissão Nacional Provisória das Comunidades Rurais Negras Quilombolas” (CONAQ, 2019, n.p.).

Em 1996, é criada a Coordenação Nacional de Articulação das Comunidades Negras Rurais Quilombolas - CONAQ, que possui caráter central e se constitui como movimento social, não se configurando como outras formas organizativas, tais como sindicatos ou partidos políticos (CONAQ, 2019). A CONAQ tem como objetivos:

\footnotetext{
lutar pela garantia de uso coletivo do território, pela implantação de projetos de desenvolvimento sustentável, pela implementação de políticas públicas levando em consideração a organização das comunidades de quilombo; por educação de qualidade e coerente com o modo de viver nos quilombos; o protagonismo e autonomia das mulheres quilombolas; pela permanência do(a) jovem no quilombo e acima de tudo pelo uso comum do território, dos recursos naturais e pela harmonia com o meio ambiente. (CONAQ, 2019, n.p.).
}

A luta quilombola no Brasil atravessou os séculos e, apesar das conquistas, tem se renovado constantemente por intermédio dos protestos e reivindicações das comunidades quilombolas, organizadas no movimento social que busca a implementação de direitos já conquistados, em meio a regras e procedimentos extremamente hierarquizados pelos órgãos governamentais responsáveis.

O movimento das comunidades quilombolas teve início na década de 1970, no Maranhão e no Pará e, posteriormente, espraiou-se por todos os estados, sendo que o maior número de comunidades encontra-se nas 
regiões onde a mão de obra escrava foi mais frequente. (FIABANI, 2017, p. 1-2).

Cabe destacar que a FCP (2019), até 12 de agosto de 2019, havia expedido 2.744 certidões, para 3.386 comunidades, em todo o país. O Gráfico 2 mostra o número de certificações expedidas pela fundação por ano, desde a implementação do Decreto $\mathrm{n}^{\circ}$ $4.887 / 2003$.

Gráfico 2: Comunidades Remanescentes de Quilombos - CRQs Certificadas por ano no Brasil

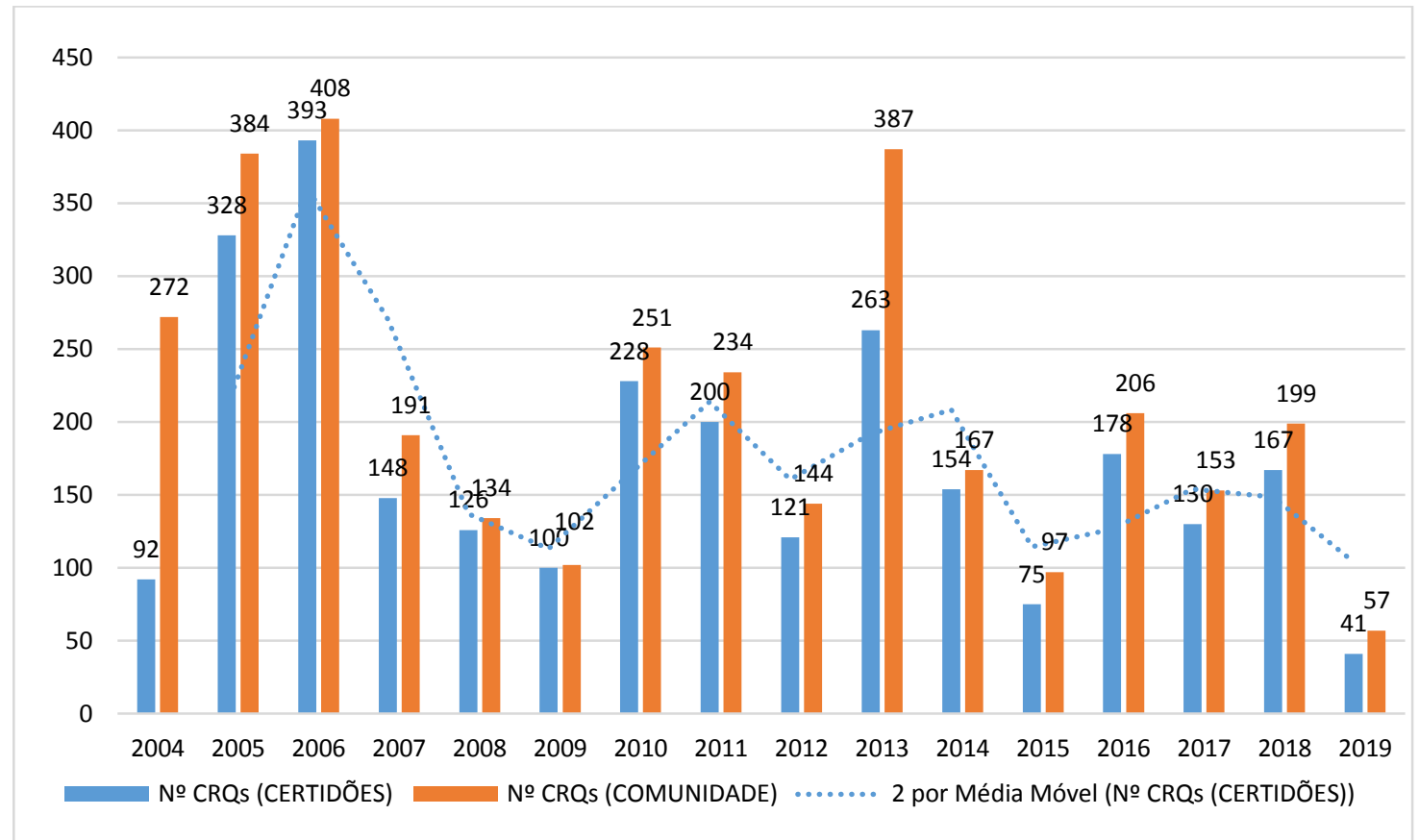

Fonte: Fundação Cultural Palmares - FCP (2019). Adaptado por Maciel (2020).

Fazendo uma análise do número de certidões emitidas em todo Brasil, é possível perceber que, nos anos de 2005 a 2006, houve uma elevação significativa dessas emissões, fato relacionado à regulamentação dos procedimentos de identificação, reconhecimento, delimitação, demarcação e titulação de territórios quilombolas, imposta pelo Decreto 4.887/2003, durante o primeiro mandato do Governo de Luiz Inácio Lula da Silva. Tal situação não se manteve no segundo mandato do referido presidente, quando se observa a queda significativa entre os anos de 2007 a 2009, voltando a se elevar somente em 2010.

Durante o governo de Dilma Vana Rousseff (2011 a 31 de agosto de 2016) a quantidade de certificações emitidas para as comunidades apresentou crescimento 
significativo nos anos de 2011 e 2013, voltando a cair em 2016, em decorrência do processo de impeachment. É importante ressaltar que o ano de 2019 apresenta uma queda significativa no número de emissões de certidões pela FCP, devido a mudanças na conjuntura política do país, na qual se nota a adoção de um modelo de desenvolvimento que impõe obstáculos para o avanço do pequeno produtor no campo brasileiro, além de falta de incentivo a reforma agrária e a titulação de territórios historicamente ocupados. O Gráfico 2 mostra a quantidade de comunidades remanescentes reconhecidas por região do Brasil.

Gráfico 2: $N^{\circ}$ de CRQs reconhecidas por região do Brasil

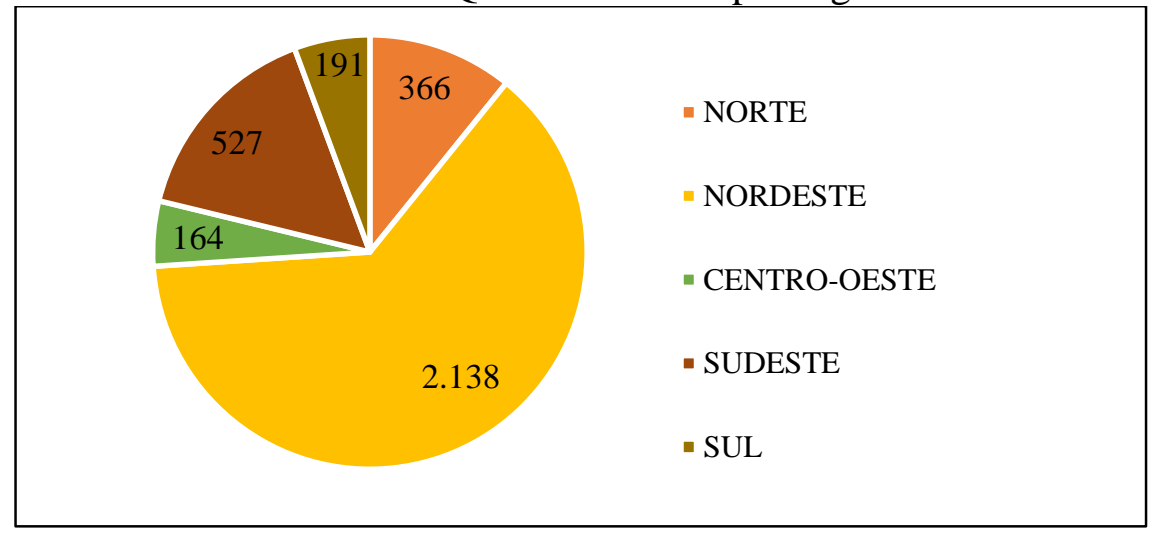

Fonte: Fundação Cultural Palmares - FCP (2019). Adaptado por Maciel (2020).

O Gráfico 2 mostra dados numéricos da região Nordeste do Brasil, surpreendentes se comparados com o restante do Brasil. Esse número elevado de certidões emitidas no Nordeste brasileiro está associado a uma época em que a base da economia colonial e imperial estava na mão de obra escrava, a qual era voltada para atender interesses de uma minoria privilegiada, que se beneficiava com os lucros das exportações.

De acordo com dados do INCRA de 16 de dezembro de 2019, em todo o Brasil existem 1.749 (um mil setecentos e quarenta e nove) processos abertos de regularização fundiária para obtenção de titulação de terras remanescentes quilombolas, sendo que a maioria desses processos estão concentrados na região Nordeste do Brasil, que possui 1.007 (um mil e sete), sendo o estado do Maranhão com maior número, 399 (trezentos e noventa e nove), como mostra o Mapa 2. 
Mapa 2: Brasil: número de comunidades quilombolas com processo de regularização fundiária junto ao INCRA

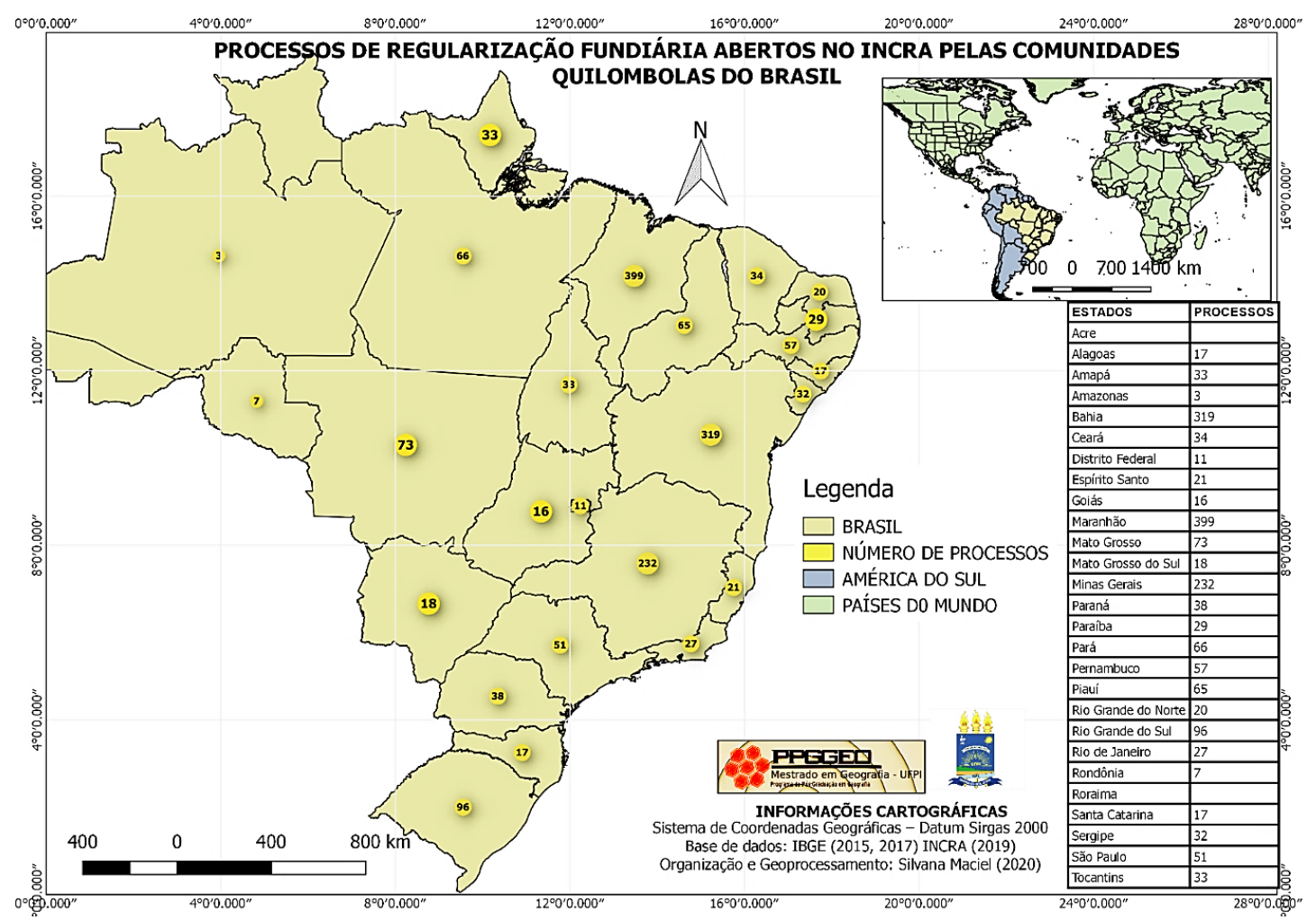

Fonte: Maciel (2020).

Banco de dados: IBGE (2015; 2017); INCRA (2019).

A região Sudeste registra 331 (trezentos e trinta e um) processos, sendo Minas Gerais, com 232 (duzentos e trinta e dois), o estado com maior número. Na região Sul, 151 (cento e cinquenta e um), onde o Rio Grande do Sul desponta com 96 (noventa e seis) processos. Na região Norte, 142 (cento e quarenta e dois), com maior número no Pará, 48 (quarenta e oito). E na região Centro-Oeste, 118 (cento e dezoito), sendo 73 (setenta e três) somente em Mato Grosso (INCRA, 2019).

As reivindicações dos grupos sociais no Brasil têm contribuído, nas últimas décadas, para a consolidação de afirmações étnico-raciais, ligadas a um passado desprovido de direitos à cidadania, democracia e liberdade, diante da hegemonia de uma elite opressora. Dessa forma, a afirmação da identidade quilombola no contexto político da atualidade se faz necessária no atendimento das necessidades e reivindicações do grupo social. 
A regularização da terra que ocupam - para preservação dos recursos e dos marcos socioespaciais importantes para a reafirmação da identidade e da cultura - além de programas e projetos capazes de promover o desenvolvimento rural, possibilitando, assim, melhores condições de vida. (MINÉ; RODRIGUES, 2012, p. 125).

As comunidades quilombolas tiveram suas identidades reconhecidas a partir da inserção do artigo 68 no ADCT da Constituição Federal de 1988, tanto no que se refere a sua "relação com os que as rodeiam - sejam as populações vizinhas, os poderes locais ou os aparelhos de Estado -, quanto nas relações entre seus próprios atores [...] com a reelaboração da memória [...] do grupo" (ARRUTI, 1997, p. 23). A partir desse reconhecimento, essas comunidades passaram a se organizar em associações comunitárias e a definirem-se como remanescentes quilombolas, fatos que levaram a uma variedade de mudanças nas relações dessas comunidades.

\section{O processo de titulação dos territórios quilombolas no Brasil}

O processo de titulação de comunidades quilombolas passa necessariamente pelo processo de certificação, bem como pelo processo de regularização fundiária. A emissão do certificado é de responsabilidade da Fundação Cultural Palmares, órgão vinculada ao Ministério da Cultura, por meio da Portaria nº 98, de 26 de novembro de 2007.

Para a emissão da certidão de autodefinição como remanescente dos quilombos deverão ser adotados os seguintes procedimentos: I - A comunidade que não possui associação legalmente constituída deverá apresentar ata de reunião convocada para específica finalidade de deliberação a respeito da autodefinição, aprovada pela maioria de seus moradores, acompanhada de lista de presença devidamente assinada; II - A comunidade que possui associação legalmente constituída deverá apresentar ata da assembleia convocada para específica finalidade de deliberação a respeito da autodefinição, aprovada pela maioria absoluta de seus membros, acompanhada de lista de presença devidamente assinada; III- Remessa à FCP, caso a comunidade os possua, de dados, documentos ou informações, tais como fotos, reportagens, estudos realizados, entre outros, que atestem a história comum do grupo ou suas manifestações culturais; IV - Em qualquer caso, apresentação de relato sintético da trajetória comum do grupo (históriada comunidade); V Solicitação ao Presidente da FCP de emissão da certidão de autodefinição. (BRASIL, 2007, Portaria n ${ }^{\circ}$ 98, Art. $3^{\circ}$ ). 
Dessa forma, para obter a autodefinição a comunidade deve requerer por meio de solicitação, encaminhada ao Presidente da FCP. A solicitação deve ser acompanhada de documento relatando a história da comunidade e ata de reunião com finalidade específica de autodefinição, aprovada e assinada pela maioria absoluta dos membros. Em seguida, a comunidade deve solicitar o pedido de regularização fundiária no INCRA, por intermédio da abertura de processo administrativo.

O Guia de Políticas para Quilombolas destaca que esse processo é executado pelo INCRA e o Ministério de Desenvolvimento Agrário - MDA, em parceria com os institutos de Terras Estaduais e Secretária de Patrimônio da União. As comunidades requerentes devem encaminhar a solicitação, fundamentada no Decreto $n^{\circ} 4.887 / 2003$, na Instrução Normativa 57/Incra de 20 de outubro de 2009, e no documento de certificação emitido pela FCP à Superintendência Regional do INCRA do seu estado de origem (SEPPIR, 2013).

Durante o processo de regularização fundiária é elaborado, na comunidade quilombola, o Relatório Técnico de Identificação e Delimitação (RTID), o qual é “composto pelo cadastramento das famílias, relatório antropológico, levantamento fundiário, planta e memorial descritivo, levantamento de dados agroambientais e pareceres técnico e jurídico" (Representante do INCRA SR 24, informação escrita, 02 de maio de 2019).

Quanto aos elementos detectados pelo RTID que melhor caracterizam a população da comunidade como remanescente de antigos quilombos, o entrevistado esclareceu que “a caracterização dos remanescentes das comunidades quilombolas é atestada mediante autodefinição, que é certificada pela Fundação Cultural Palmares" (Representante do INCRA SR 24, informação escrita, 02 de maio de 2019). Assim, o RTID é o resultado de estudos técnicos e científicos voltados à caracterização do território ocupado pelas comunidades remanescentes de quilombos.

A titulação de territórios quilombolas passa necessariamente pela autodefinição da comunidade, que deve apresentar ao INCRA a certidão de autodefinição emitida pela Fundação Palmares, para elaboração do Relatório Técnico de Identificação e Delimitação (RTID), que consiste no levantamento das informações históricas, geográficas, cartográficas, fundiárias, agronômicas, socioeconômicas, ecológicas, etnográficas e antropológicas da comunidade (Figura 1). 
Figura 1: Fluxograma do processo de titulação dos territórios quilombolas de acordo com a Instrução Normativa INCRA no 57/2009.

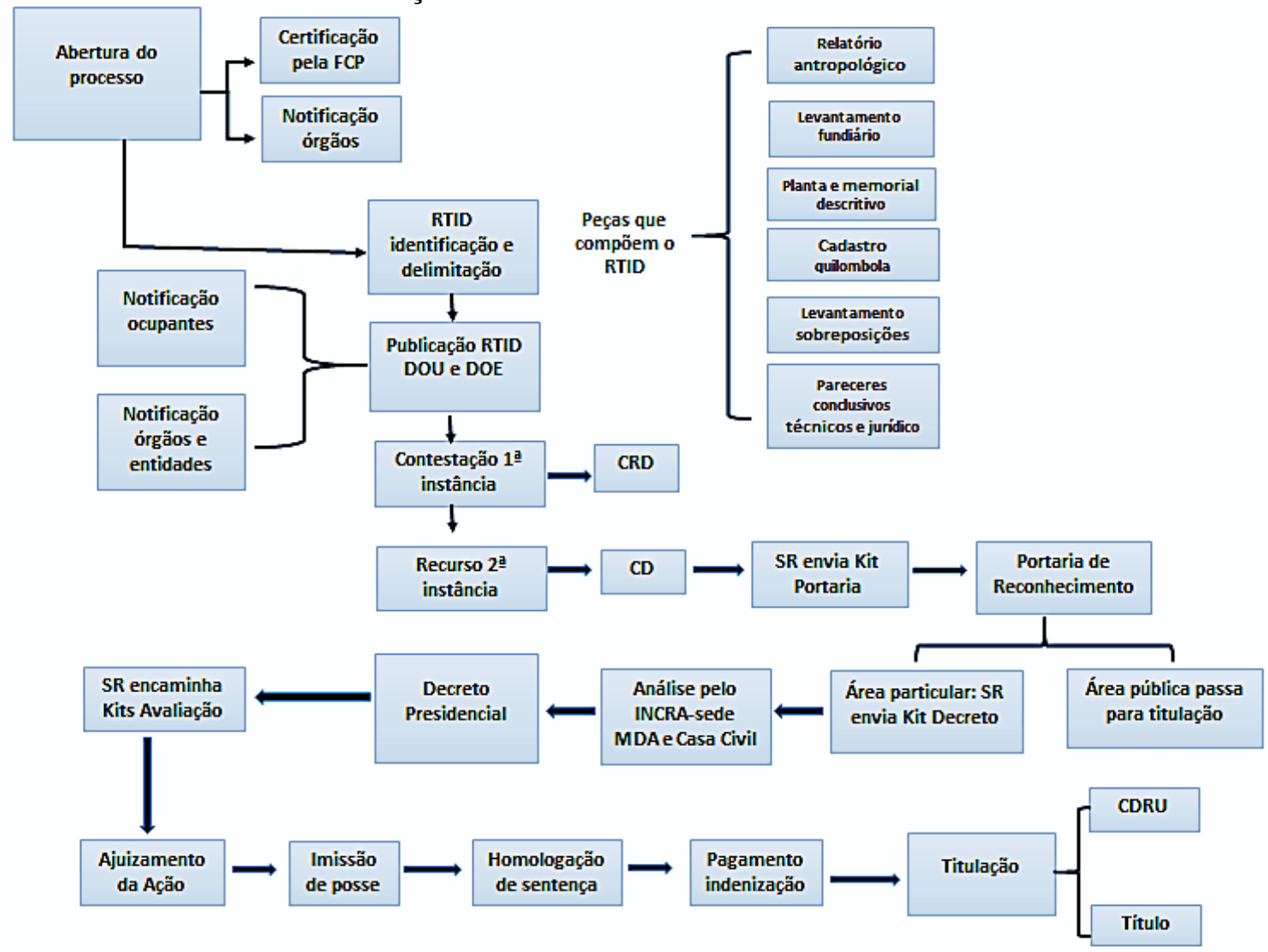

Fonte: INCRA SR 24 (2019). Adaptado por Maciel (2020).

As informações para o RTID podem ser obtidas em campo, com os remanescentes das comunidades quilombolas e através de parcerias com instituições, tanto públicas como privadas, nas quais é possível identificar os limites dos territórios da comunidade quilombola. Sobre o processo de regularização das terras de quilombos, Arruti (2016, p. 242) afirma que não é "prioritariamente cultural, mas territorial: a diversidade cultural é apenas subsidiária, uma manifestação quase acidental dos direitos territoriais".

Findada a elaboração do RTID, este é publicado pelo INCRA, que estabelece o prazo de 90 dias para contestação, mediante apresentação de provas, cabendo recurso único ao conselho diretor do INCRA (sede), durante o prazo de 30 dias após a contestação do relatório (INCRA, 2019).

No que se refere às medidas adotadas pelo INCRA e/ou pela comunidade remanescente a fim de acabar com as possíveis dificuldades encontradas no decorrer do processo de regularização fundiária, o entrevistado argumentou que 
[...] o que facilita muito o trabalho durante o longo processo de regularização fundiária dos territórios quilombolas é proporcionar à comunidade acesso aos procedimentos adotados. Cada etapa do trabalho deve ser sempre precedida de reuniões com a comunidade e o Grupo Técnico responsável pelos estudos. A participação da comunidade interessada em todas as fases do procedimento administrativo contribuiu para o bom andamento dos trabalhos. (Representante do INCRA SR 24, informação escrita, 02 de maio de 2019).

Para finalizar a fase de identificação do território remanescente de quilombo, o INCRA publica uma portaria reconhecendo os limites do território reivindicado no diário oficial da União e dos Estados.

É válido lembrar que em algumas comunidades quilombolas existem imóveis privados, adquiridos por meio de titulação ou posse, que incidem no território dos remanescentes. Nesses casos, é necessária a publicação de decreto de desapropriação por interesse social, emitido pela Presidência da República.

Em casos de desapropriações, os imóveis privados são vistoriados e avaliados com base no preço de mercado, os posseiros recebem o pagamento em dinheiro da terra nua, enquanto para os titulados são pagas também as benfeitorias.

Quando foram solicitados esclarecimentos relativos aos procedimentos e/ou medidas que serão adotados pelo INCRA, no sentido de contribuir para o andamento do processo de aquisição dos territórios dos remanescentes quilombolas foi reforçado que

[...] a política de regularização fundiária de quilombos é regulamentada atualmente pelo Decreto 4.887/2003, cabendo ao Incra, órgão estaduais e municipais a execução concorrente dessa ação fundiária. A Instrução Normativa - IN 57/2009/INCRA normatiza o procedimento de identificação, reconhecimento, delimitação, demarcação e titulação das terras ocupadas pelos remanescentes. (Representante do INCRA SR 24, informação escrita, 02 de maio de 2019).

Questionou-se também se, além da posse comunitária da terra, haveria outros benefícios socioeconômicos a serem adquiridos pelos remanescentes quilombolas com a regularização fundiária. Sobre essa questão foi relatado que a segurança jurídica advinda com a regularização e titulação de seu território, garante à população quilombola sua reprodução física, social, econômica e cultural.

Foi informado pelo entrevistado que, para além das ações voltadas para a regularização fundiária, existem outros instrumentos e políticas que garantem a 
preservação das características culturais dessas comunidades. São exemplos o PNRA Programa Nacional de Reforma Agrária, que prevê ações de promoção do etnodesenvolvimento e de garantia da segurança alimentar e nutricional das comunidades quilombolas, como também o Programa Nacional de Educação na Reforma Agrária (PRONERA), que propõe e apoia projetos de educação voltados para assentamentos e comunidades quilombolas.

A respeito do tamanho dos terrenos nas comunidades, questionou-se se ocorre alguma modificação nas suas medidas após titulação do território remanescentes de quilombo. Foi informado que a titulação do território é coletiva e pro indiviso à comunidade, em nome de sua associação legalmente constituída. Assim, a organização das áreas ocupadas por cada família dentro do território fica sob a responsabilidade da própria comunidade quilombola. $\mathrm{O}$ direito privado da família sobre a área que ela ocupa se dá pelo respeito aos códigos locais e não por nenhuma divisão legal ou cartorial.

Encerradas todas as fases da regularização fundiária, a comunidade recebe a titulação, mediante a outorga de título coletivo, imprescritível e pro indiviso em nome da Associação Comunitária legalmente constituída, sem nenhum ônus financeiro, sendo a venda e a penhora do território proibida (INCRA, 2019).

Quanto aos critérios exigidos pelo Governo Federal para que as famílias tenham acesso aos benefícios do Programa Brasil Quilombola, o entrevistado destacou que o referido programa

[...] foi criado em 2004 com base no Decreto 4.887/03, e a legislação reconhece como critério para determinação de comunidades quilombolas, a autodefinição. Esse critério está reconhecido no artigo $2^{\circ}$ do Decreto 4. 887/2003 e também está presente na Convenção 169 da OIT que estabelece o critério de autoidentificação como fundamental para identificar os sujeitos de sua aplicação. (Representante do INCRA SR 24, informação escrita, 02 de maio de 2019).

Diante do exposto, evidencia a competência do Estado em tornar acessível e promover o encontro das políticas públicas à população quilombola. De acordo com Arruti (2009, p. 78), o Programa Brasil Quilombola "reúne um conjunto de ações e propostas dispersas por diversos ministérios e secretárias, dando-lhes não exatamente um sentido orgânico, mas no máximo, coordenado”. Assim, as políticas públicas destinadas 
as comunidades quilombolas se caracterizam por serem instituídas dentro de um modelo descentralizador que colabora para acentuar a efetivação dessas políticas.

Nesse contexto, é importante lembrar que os movimentos sociais do campo estão insatisfeitos e criticam as falhas na titulação dos territórios de quilombos, "cuja morosidade na obtenção dos títulos coletivos da terra deixa as comunidades em situação vulnerável e, entre outras consequências, impedidas de acessar a outras políticas públicas" (FERREIRA; SOUZA, 2017, p.2).

Assim, a entrevista com o representante do INCRA SR 24 foi extremamente esclarecedora sobre o processo de regularização fundiária dos territórios remanescentes quilombolas no Brasil, percebeu-se que, apesar de alguns avanços, ainda existe um longo caminho a ser percorrido pelas comunidades quilombolas do país.

A regularização de territórios quilombolas no Brasil, desde o artigo 68 dos ADCT, tem passado por ajustes e aperfeiçoamentos. No entanto, o processo se caracteriza por ser burocrático e lento, deixando as comunidades, por décadas, aguardando a sua tramitação e a tão almejada titulação do território. Enquanto isso, inúmeras delas vivem no anonimato, entre conflitos e incertezas quanto à garantia de conquistar o que é seu por direito, realidade que não se diferencia no Piauí.

\section{Considerações finais}

O ponto de partida da problemática que envolve a titulação dos territórios quilombolas no Brasil está na imposição da escravidão, que forçou a adaptação e aceitação pelos negros a uma cultura que não retratava as suas raízes, causando revoltas e alimentando o desejo de liberdade e participação nessa nova sociedade impregnada de ideologias preconceituosas.

A resistência do negro está pautada na busca por respeito, dignidade, inserção e participação social. Nesse contexto, a luta pelo território tem sido uma constante na vida dos remanescentes de quilombos dentro de várias comunidades brasileiras, pois estas foram excluídas historicamente do processo de distribuição das terras no país.

A inclusão do artigo 68 no ADCT da Constituição Federal colaborou de modo expressivo para a consagração do princípio da igualdade, pois se constituiu no 
reconhecimento de uma luta que perpassou séculos, na medida em que transformou as posses de terras de antigos quilombos em domínio por direito.

Nessa perspectiva, enfatiza-se que a efetivação do direito ao território quilombola, desde a sua regulamentação e normatização, tem ocorrido de forma burocrática e insatisfatória, levando em consideração a quantidade de comunidades remanescentes que aguardam a sua tramitação. Essa situação acaba por favorecer a permanência e perpetuação de grandes extensões de terra em nome da União, dos Estado da federação e de grandes proprietários, que nem sempre as utilizam.

A titulação das terras remanescentes quilombolas contribui para a manutenção das tradições do grupo, colaboram para a preservação das reservas florestais, amenizando as possíveis consequências do avanço do agronegócio sobre áreas consideradas essenciais para subsistência das famílias ali residentes.

Os quilombolas devem proteger-se, e elevar a autoestima num movimento de resistência atrelado a uma educação conscientizadora do sentimento de pertencimento à comunidade/território quilombola, buscando sempre a efetivação de políticas públicas e ações de programas governamentais que possam ser implementados.

Destarte, a titulação dos territórios quilombolas por meio da regularização fundiária prevê diversos benefícios para garantir a manutenção e subsistência por intermédio das políticas públicas de grande importância para a inserção social e econômica dos remanescentes.

Entende-se que as comunidades quilombolas do Brasil apresentam diversas limitações e fragilidades no campo político e institucional. Tais comunidades necessitam, ainda, elevar seus conhecimentos quanto aos trâmites legais e burocráticos que envolvem as solicitações de projetos de desenvolvimento local. Para tanto, uma maior articulação das associações comunitárias, frente as demandas dessas comunidades, é necessária, visando a melhoria do seu futuro próximo.

\section{REFERÊNCIAS}

ALBUQUERQUE, Wlamyra R. de; FRAGA FILHO, Valter. Uma história do negro no Brasil. Salvador: Centro de Estudos Afro-Orientais. Brasília: Fundação Cultural Palmares, 2006. 
ALMEIDA, Alfredo Wagner Berno de. Terra de quilombo, terras indígenas, "babaçuais livre","castanhais do povo", faixinais e fundos de pasto: terras tradicionalmente ocupadas. 2. ed. Manaus: PGSCA-UFAM, 2008.

ANJOS, R. S. A. dos. O espaço geográfico dos remanescentes de antigos quilombos no Brasil. Rev. Bras. Extensão Universitária, Rio de Janeiro, v.1 n.1, p, 52-57, jul-dez 2003.

ARRUTI, José Maurício. Entre campo e cidade: quilombos, hibridismos conceituais e vetores de urbanização. In: OLIVEIRA, Osvaldo Martins de (org.). Direitos quilombolas \& dever de Estado em 25 anos da Constituição Federal de 1988. Rio de Janeiro: Associação Brasileira de Antropologia, 2016.

José Maurício Andion. "Políticas Públicas para quilombos: terra, saúde e educação". In: PAULA, Marilene de; HERINGER, Rosana (org.). Caminhos Convergentes: Estado e Sociedade na Superação das desigualdades Raciais no Brasil. ed 1. Vol. 1, 75-110. Rio de Janeiro: Fundação Henrich Boll, Action AID, 2009.

José Maurício Andion. "A emergência dos remanescentes": notas para o diálogo entre indígenas e quilombolas". Rio de Janeiro. In: revista Mana. $n^{\circ}$ 2, Vol. 3, Museu Nacional, outubro de 1997.

BERND, Zilá. Racismo e anti-racismo. São Paulo: Moderna, 1994. (Coleção polêmica).

BRASIL. Constituição da República Federativa do Brasil: 1988. Câmara dos Deputados, Coordenação de Publicações. Brasília, DF, 1988.

Decreto $n^{0}$ 4.887, de 20 de novembro de 2003. Disponível em:

https://presrepublica.jusbrasil.com.br/legislacao/98186/decreto-4887-03. Acesso em: 22 jul. 2017.

Portaria $\mathbf{n}^{\mathbf{0}}$ 98, de 26 de novembro de 2007. Disponível em: http://www.palmares.gov.br/wp-content/uploads/2010/11/legis21.pdf. Acesso em: 23 fev. 2021

CANUTO, Antônio; LUZ, Cássia Regina da Silva; ANDRADE, Thiago Valentim Pinto (Coord.). Conflitos no campo - Brasil 2015. Goiânia: Comissão Pastoral da Terra CPT Nacional - Brasil, 2018.

CONAQ - Coordenação Nacional de Articulação das Comunidades Negras Rurais Quilombolas. Quilombo? Quem somos nós? Disponível em: http://conaq.org.br/quemsomos/. Acesso em: 17 nov. 2019.

FIABANI, Adelmir. Comunidades Remanescente de Quilombo: da invisibilidade à luta pela terra. In: LIMA, Solimar Oliveira; FIABANI, Adelmir. Sertão quilombola: comunidades negras rurais no Piauí. Teresina: EDUFPI, 2017. 
FUNDAÇÃO CULTURAL PALMARES - FCP. Certidões expedidas às comunidades remanescentes de quilombos (CRQs) atualizada até a portaria $n^{0} 34 / 2019$, publicada no DOU de 12/08/2019. Disponivel em:

http://www.palmares.gov.br/?page_id=37551. Acesso em: 10 jan. 2020.

FERREIRA, Patrícia Macedo; SOUZA, Lincoln Moraes de. Avaliação da política pública de demarcação dos territórios quilombolas do Piauí: o caso da comunidade Contente. VIII Jornada Internacional Políticas Públicas. Universidade Federal do Maranhão - Programa de Pós-Graduação em Políticas Públicas, 2017. Disponível em: http://www.joinpp.ufma.br/jornadas/joinpp2017/pdfs/eixo12/avaliacaodapoliticapublica dedemarcacaodosterritoriosquilombolasdopiauiocasodacomunidadecontente.pdf. Acesso em: 14 de mai. 2018.

GIL, Antonio Carlos. Métodos e técnicas de pesquisa social. 6.ed. São Paulo: Atlas, 2009.

GIRARDI, Eduardo Paulon. A luta pela terra e sua conquista. Atlas da questão agrária brasileira. Disponível em:

http://www2.fct.unesp.br/nera/atlas/luta_pela_terra.htm. Acesso em: 10 de dez. 2019.

HAESBAERT, Rogério. Territórios alternativos. Niterói: EdUFF. São Paulo: CONTEXTO, 2002.

INÁCIO, Jaqueline Borges; SANTOS, Rosselvelt José. Os povos tradicionais e a sociobiodiversidade nas RESEX de Barra do Pacuí e Buritizeiro-Mesorregião do Norte de Minas Gerais. Sociobiodiversidade - v. 8, n. 1, abril, 2018. Disponível em: file:///C:/Users/Silvana/Downloads/7789-Texto\%20do\%20artigo-28364-1-1020180608.pdf. Acesso em: 12 fev. 2021.

INSTITUTO BRASILEIRO DE COLONIZAÇÃO E REFORMA AGRÁRIA - INCRA. Passo a passo da titulação de territórios quilombolas. Disponível em:

http://www.incra.gov. br/passo_a_passo_quilombolas. Acesso em: 5 abr. 2019.

Territórios quilombolas. Processos abertos por região/2019. Disponível em: http://www.incra.gov.br/sites/default/files/incra-processosabertos-quilombolas-v2.pdf. Acesso em: 11 jan. 2020.

INSTITUTO BRASILEIRO DE GEOGRAFIA E ESTATÍSTICA - IBGE. Bases Cartográficas (2015). Disponível em: https://mapas. ibge.gov.br/bases-ereferenciais/bases-cartograficas/malhas-digitais. Acesso em: 22 de jul. 2018.

. Malha Municipal (2017). Disponível em: https://www.ibge.gov.br/geociencias /organizacao-do-territorio/malhas-territoriais/15774-malhas.html?=\&t=downloads. Acesso em: 12 set. 2019.

LAKATOS, Eva Maria; Marconi, Marina de Andrade. Fundamentos de metodologia científica. 7.ed. São Paulo: Atlas, 2010. 
MINÉ, Gisele Oliveira; RODRIGUES, Ludimila de Miranda. Associativismo quilombola: a luta pelos múltiplos usos do território. In: TUBALDINI, Maria Aparecida dos Santos; GLANASI, Lussandra Martins (org.). Agricultura familiar, cultura camponesa e novas territorialidades no Vale do Jequitinhonha: gênero, biodiversidade, patrimônio rural, artesanato e agroecologia. Belo Horizonte, MG: Fino Traço, 2012.

MOURA, Clóvis. Quilombos: resistência ao escravismo. Série Princípios. 3.ed. São Paulo. Editora: Ática, 1993.

OLIVEIRA, Fátima. Ser negro no Brasil: alcances e limites. Estudos Avançados. 18 (50), 2004. Disponível em: https://www.scielo.br/pdf/ea/v18n50/a06v1850.pdf. Acesso em: 23 fev. 2021.

OLIVEIRA, Ariovaldo Umbelino de. A Geografia das lutas no campo. 6 ed. São Paulo: Contexto, 1994.

PEREIRA, Almilcar Araújo. “O Mundo Negro": a constituição do movimento negro contemporâneo no Brasil (1970-1995). 2010. Tese (Doutorado em História). Programa de Pós-graduação em História. Universidade Federal Fluminense, Niterói, 2010.

Disponível em: https://www.historia.uff.br/stricto/td/1254.pdf. Acesso em: 4 de jul. 2018.

REIS, João José; GOMES, dos Santos. Liberdade por um fio: história dos quilombos no Brasil. 1.ed. São Paulo: Claro Enigma, 2012.

SECRETARIA DE POLÍTICAS DE PROMOÇÃO DA IGUALDADE RACIAL SEPPIR. Guia de Políticas Públicas para Comunidades Quilombolas - Programa Brasil Quilombola. Brasília, 2013. Disponível em: https://www.gov.br/mdh/pt$\mathrm{br} /$ centrais-de-conteudo/igualdade-racial/guia-de-politicas-publicas-para-comunidadesquilombolas/view. Acesso em: 18 mar. 2018.

SUPERINTENDÊNCIA REGIONAL DO INCRA NO PIAUÍ - (SR 24). Planilha de processos quilombolas INCRA-PI. Serviço de regularização de territórios quilombolas - SR (24) PI/F4, 2019.

TRECCANI, Girolamo Domenico. Terras de Quilombo: caminhos e entraves do processo de titulação. Belém: Secretária executiva de justiça. Programa Raízes, 2006. Disponível em: https://direito.mppr.mp.br/arquivos/File/Girolamo.pdf. Acesso em: 7 de jun. 2019.

Recebido em 20/04/2020.

Aceito para publicação em 23/09/2020. 